Sari Pediatri, Vol. 6, No. 4, Maret 2005: 188-196

\title{
Leukemia Kutis
}

\author{
Melissa Gandi, Endang Windiastuti, Djajadiman Gatot
}

\begin{abstract}
Dilaporkan seorang anak perempuan, A, usia 16 bulan dengan diagnosis Leukemia Mieloblastik Akut - M2 (LMA-M2) dengan infiltrasi leukemia ke kulit (leukemia kutis) berdasarkan hasil aspirasi sumsum tulang dan biopsi kulit. Manifestasi klinis dari leukemia kutis terdiri dari nodus multipel kebiruan numular yang tersebar, diameter $2-3 \mathrm{~cm}$, berbatas tegas, tidak nyeri, pada wajah, ekstremitas atas dan bawah. Hasil pemeriksaan jaringan biopsi kulit menunjukkan infiltrasi sel-sel leukemia pada dermis dan subkutis. Pasien diberi kemoterapi sesuai protokol LMA, sedangkan antibiotik dan transfusi diberikan sesuai indikasi. Prognosis pada pasien ini buruk, karena dengan adanya leukemia kutis (LK) pada LMA, perjalanan penyakit menjadi agresif. Pasien meninggal 2 bulan setelah timbulnya lesi kulit.
\end{abstract}

Kata kunci : leukemia mieloblastik akut, leukemia kutis, nodus numular

$\sim$ ukemia kutis merupakan infiltrasi sel-sel leukemia yang bersifat agresif ke dalam lapisan epidermis, dermis maupun subkutis. Hal ini biasanya terjadi pada akhir perjalanan penyakit leukemia, dan merupakan petanda prognosis yang buruk. ${ }^{1,2}$

Leukemia kutis merupakan leukemia ektramedular yang jarang dijumpai. ${ }^{1} \mathrm{Hal}$ ini sesuai dengan data dari rekam medik di Departemen Kulit dan Kelamin RSCM sejak Januari 1991 sampai Mei 2004, hanya didapatkan 3 kasus LK pada anak. Di Amerika Serikat dari 2,5 kasus dari leukemia mieloblastik akut, 13\% menderita LK. ${ }^{1}$ Sajian kasus ini sebagai kasus demonstrasi LMA dengan infiltrasi ke kulit.

\section{Kasus}

Seorang anak perempuan A, usia 14 bulan, dirujuk ke RS Dr. Cipto Mangunkusumo (RSCM) Jakarta

\footnotetext{
Alamat korespondensi:

Dr Endang Windiastuti, Sp.A(K)

Staf Divisi Hematologi-Onkologi. Departemen Ilmu Kesehatan Anak FKUI-RSCM.

Jl. Salemba no. 6, Jakarta 10430

Telepon: 021-3907744, 31901170 Fax.021-3913982.

Dr. Melissa Gandhi. PPDS Bag Anak
}

tersangka leukemia akut pada tanggal 4 November 2003. Pada pemeriksaan fisis saat pertama kali dirawat di RSCM (tanggal 4 November 2003) pasien tampak pucat disertai manifestasi perdarahan gusi dan kulit. Tidak terdapat limfadenopati. Paru dan jantung tidak ditemukan kelainan. Hati teraba $4 \mathrm{~cm}$ di bawah arkus kosta dan $3 \mathrm{~cm}$ di bawah processus xyphoideus, tepi tajam, permukaan rata, konsistensi kenyal. Limpa membesar pada Schuffner I.

Hasil pemeriksaan darah tepi (tanggal 4 November 2003) di dapatkan kadar hemoglobin $(\mathrm{Hb}) 5 \mathrm{~g} / \mathrm{dL}$, hematokrit $(\mathrm{Ht}) 15 \mathrm{vol} \%$, leukosit $(\mathrm{L})$ $4900 / \mathrm{mL}$, trombosit $(\mathrm{Tr}) 19.000 / \mathrm{mL}$, hitung jenis (\%): basofil 0 , eosinofil 0 , batang 0 , segmen 18 , limfosit 79, monosit 3 dan ditemukan sel blas. Saat itu di tegakkan diagnosis kerja sebagai tersangka leukemia akut dan gizi kurang. Sediaan sumsum tulang yang dilakukan dua kali tipis (dry tap), sehingga sulit diinterpretasi. Pasien diberi transfusi packed rd cell (PRC) dan suspensi trombosit secara serial. Pasien berobat jalan teratur setiap minggu, tetapi orangtua tidak mengijinkan tindakan aspirasi sumsum tulang ulang.

Pada usia 15 bulan (satu bulan kemudian) mulai timbul bercak-bercak kebiruan yang menonjol pada wajah dan ekstremitas, dengan 
diameter 1-2 cm, tidak gatal, tidak nyeri, tanpa riwayat trauma maupun alergi obat (Gambar 1).

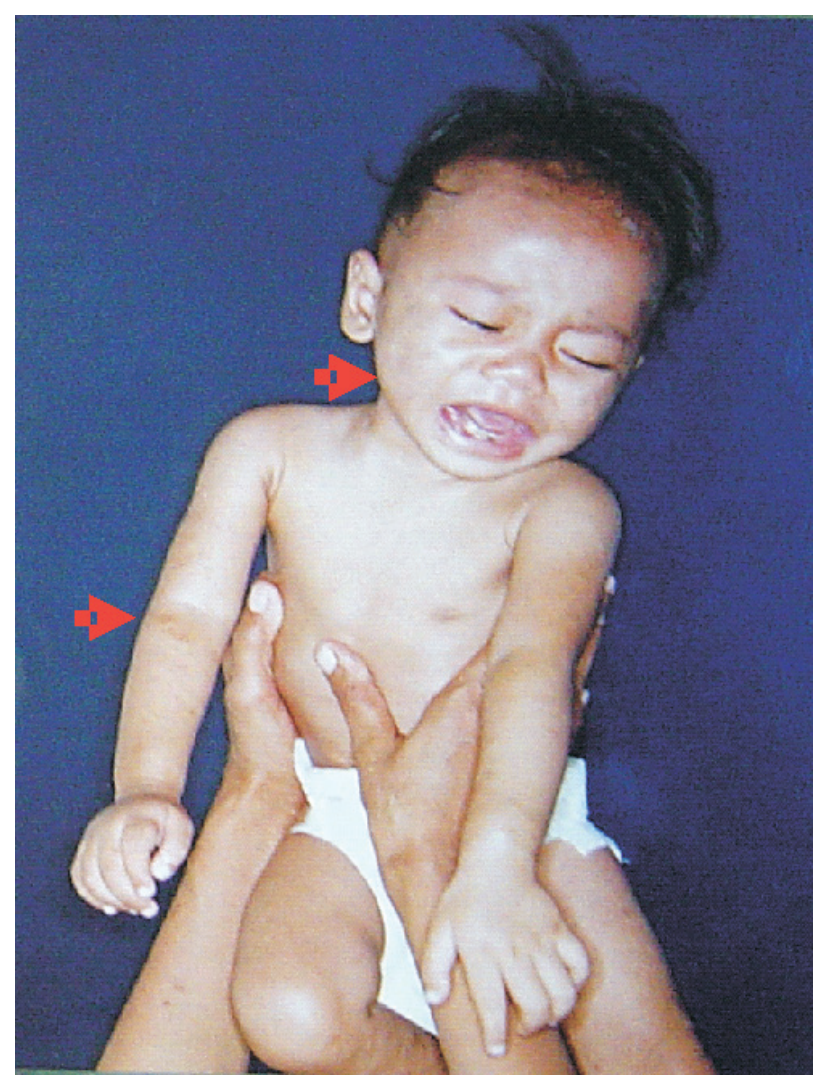

Gambar 1. Pasien usia 15 bulan dengan bercak-bercak kebiruan pada wajah dan ekstremitas
Saat itu dipikirkan kemungkinan diagnosis leukemia kutis dengan diagnosis banding nodus neuroblastoma subkutan. Pada pemeriksaan ultrasonografi abdomen tidak tampak masa, sedangkan pada pemeriksaan bone survey tampak lesi litik pada tulang panjang, tidak dijumpai metastasis tumor (Gambar 2). Dianjurkan pemeriksaan biopsi kulit, tetapi orangtua menolak.

Pada usia 16 bulan (dua bulan kemudian), pasien tampak sangat pucat dengan bercak-bercak kulit yang makin menyebar di wajah dan ekstremitas. Pasien dirawat untuk kedua kalinya di RSCM untuk dilakukan transfusi darah, biopsi kulit serta pengulangan pemeriksaan sumsum tulang. Pemeriksaan fisis saat dirawat kedua-kalinya tanggal 12 Januari 2004 didapatkan keadaan umum tampak pucat dan lemah, kesadaran kompos mentis, tidak didapatkan tanda distres pernafasan. Berat badan $8 \mathrm{~kg}(<\mathrm{P} 3 \mathrm{NCHS})$, panjang badan $75 \mathrm{~cm}$, dengan suhu $37,5^{\circ} \mathrm{C}$.

Pada pemeriksaan kulit didapatkan banyak nodus kebiruan numular dengan diskret multipel, diameter 2-3 cm, berbatas tegas, dan tidak nyeri pada wajah, ekstremitas atas dan bawah (Gambar 3). Tidak tampak petekie atau tanda perdarahan lain. Tidak ada pembesaran kelenjar getah bening, jantung dan paru normal. Hati teraba $4 \mathrm{~cm}$ di bawah arkus kosta dan $3 \mathrm{~cm}$ di bawah processus xyphoideus, kenyal, sehingga limpa membesar pada ukuran Schuffner II.

Pemeriksaan darah tepi tanggal 12 Januari 2004 didapatkan $\mathrm{Hb} 3,7 \mathrm{~g} / \mathrm{dL}, \mathrm{L} 11.600 / \mathrm{mL}, \operatorname{Tr} 68.000 /$

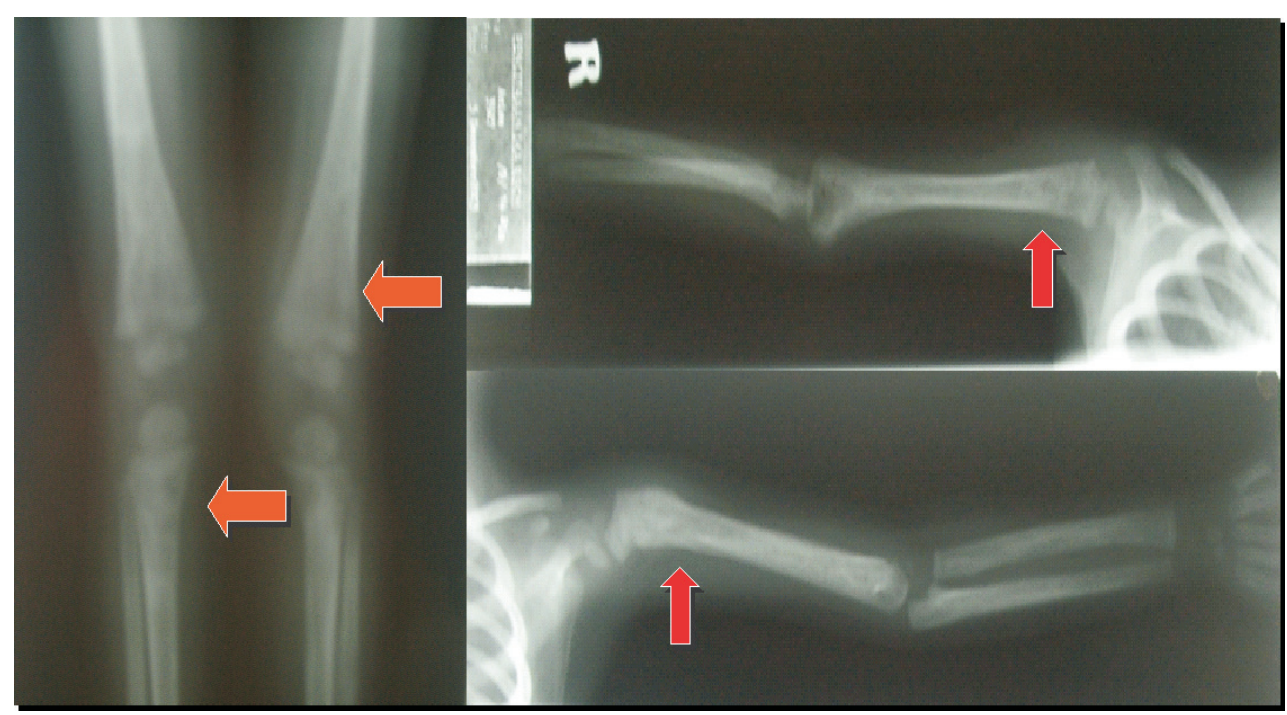

Gambar 2. Bone survey: lesi litik pada tulang-tulang panjang 


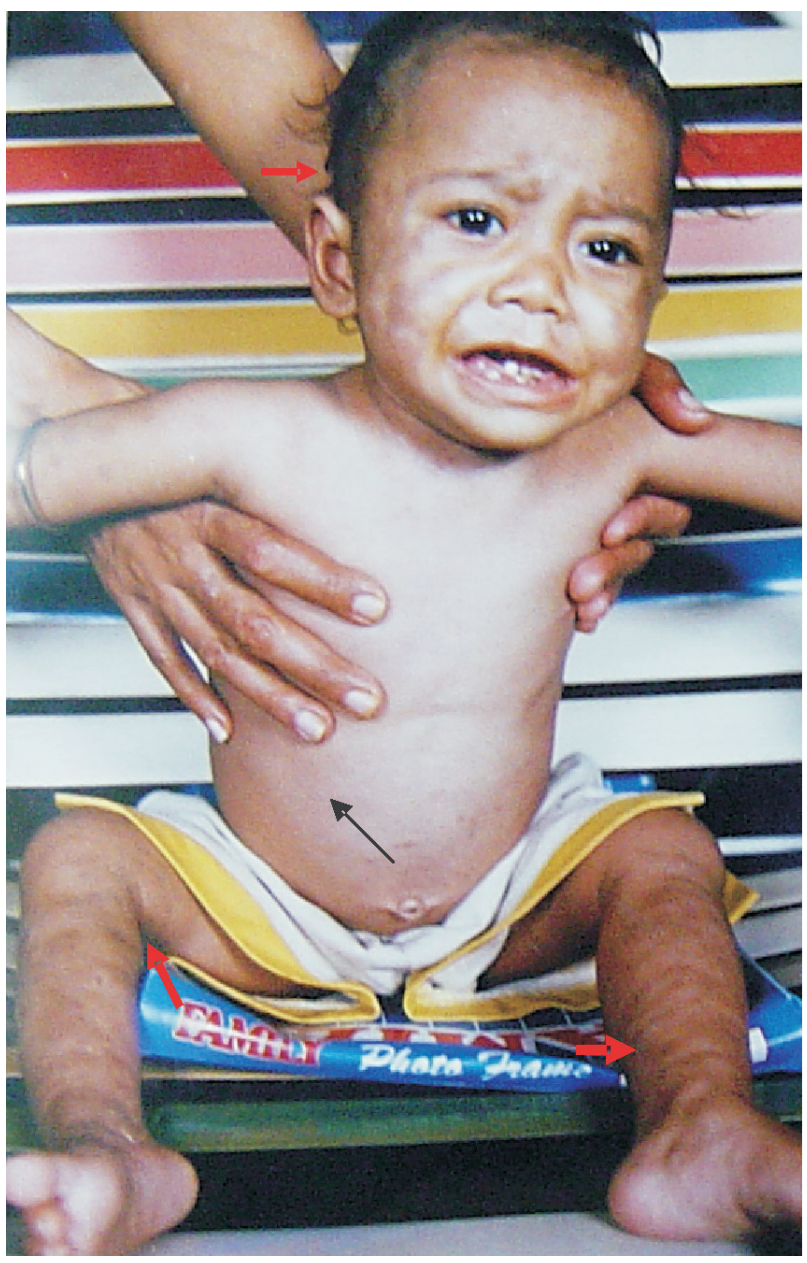

Gambar 3. Pasien usia 16 bulan dengan nodus kebiruan numular

$\mathrm{mL}$. Hitung jenis (\%): basofil 0, eosinofil 0, batang 0 , segmen 10, limfosit 87 dan monosit 3. Apusan darah tepi menunjukkan normositik hipokromik, terdapat tear drop cells, anisositosis, dan sel blas (Gambar 4).

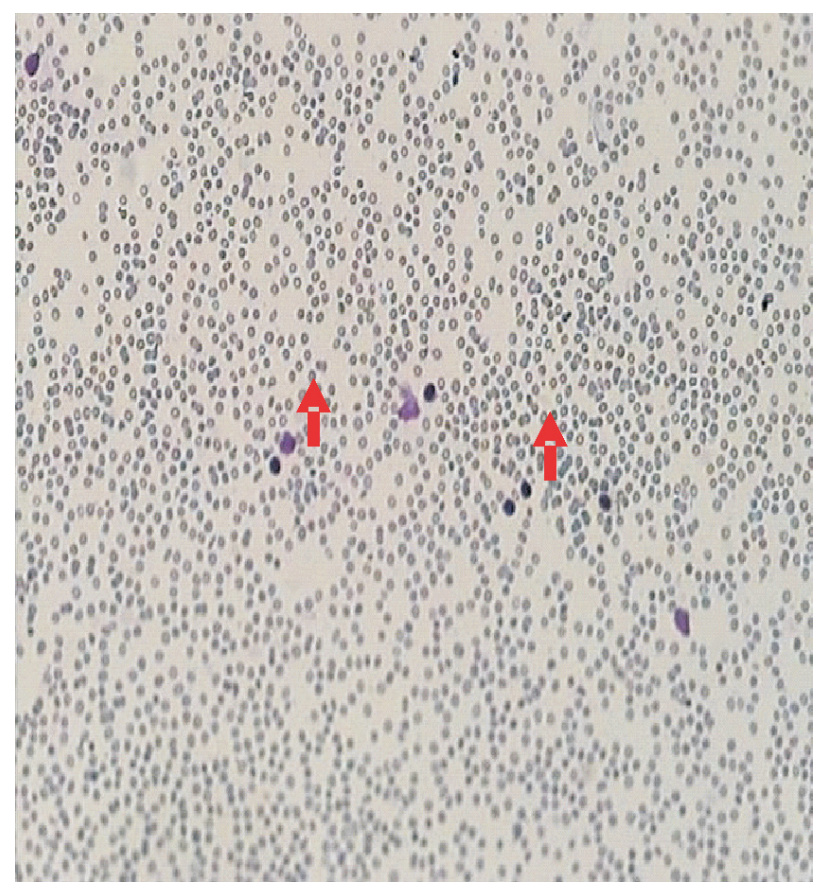

Gambar 4. Sel blas pada apusan darah tepi

Saat perawatan pasien diberi transfusi PRC serial dan dikonsulkan ke Departemen Kulit dan Kelamin untuk dilakukan biopsi kulit.

Pada minggu pertama perawatan kedua timbul demam $38,6^{\circ} \mathrm{C}$ dan diare. Hasil analisis feses dijumpai infeksi bakteri gram negatif dan maldigesti karbohidrat. Pasien diberi sefotaksim intra vena (IV) dan enzim pencernaan. Pada hasil kultur darah dijumpai Acinetobacter calcoaceticus, dengan hasil uji resistensi intermediate terhadap sefotaksim dan hasil pemeriksaan histopatologi biopsi kulit menunjukkan infiltrasi sel leukemia pada dermis dan subkutis (Gambar 5).

Pada minggu ke-3 perawatan, pasien demam lagi
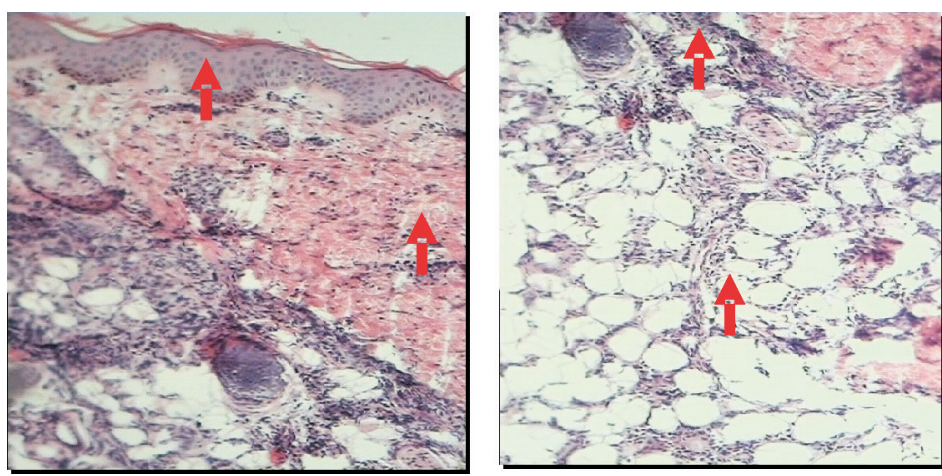

Gambar 5. Hasil biopsi kulit

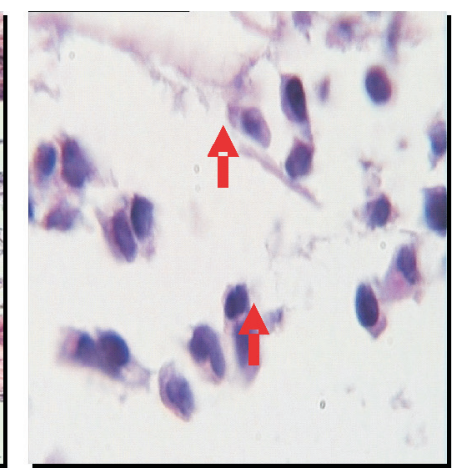


disertai batuk pilek. Nodus kebiruan makin menebal, menyebar sampai ke telapak kaki, disertai pembesaran kelenjar getah bening multipel dengan diameter 0,3$1 \mathrm{~cm}$ di leher dan inguinal (Gambar 6). Foto radiologi toraks menunjukkan peningkatan infiltrat di daerah parakardial dan perihilar bilateral, tidak dijumpai pembesaran kelenjar getah bening hilus, maupun masa di mediastinum anterior (Gambar 7). Hasil konsultasi ke Divisi Pulmonologi Anak RSCM menunjukkan pasien menderita batuk kronik berulang tersangka pneumonia atipik, dianjurkan pemberian klaritromisin. Demam dan batuk pilek membaik sesudah pemberian klaritromisin $15 \mathrm{mg} / \mathrm{kg} /$ hari per oral selama 7 hari.

Hasil pemeriksaan sumsum tulang pada Gambar 8 sesuai dengan Leukemia Mieloblastik Akut-M2. Hasil pemeriksaan cairan serebrospinal normal tidak ditemukan sel leukemia. Pasien diberikan kemoterapi sesuai protokol LMA yaitu vinkristin $0,4 \mathrm{mg}$ IV, siklofosfamid $55 \mathrm{mg}$ IV, metrotrelate (MTX) 5 $\mathrm{mg}+$ deksametason $0,5 \mathrm{mg}$ + ara-C $10 \mathrm{mg}$ intratekal. Pasien meninggal setelah satu kali pemberian kemoterapi yang didahului dengan muntah-muntah dan kejang.

\section{Diskusi}

Insiden infiltrasi sel leukemik pada kulit sangat jarang, namun dapat terjadi pada semua tipe leukemia. Insiden sangat bervariasi, tergantung pada tipe leukemia. ${ }^{1,3,4}$ Leukemia kutis terbanyak terdapat pada LMA-M4 dan M5 sekitar 10-50\%, sedangkan pada LMA-M0, M1, M2, M3 sampai $10 \% .^{1,4-7}$ Sekitar $25-30 \%$ bayi dengan leukemia kongenital menderita LK dan mayoritas adalah LMA. Tidak ada data tentang LK yang berhubungan dengan ras yang spesifik, seks, dan umur. ${ }^{1,8}$

Hubungan awitan LK dengan leukemia sangat bervariasi. ${ }^{4,7,9}$ Lima puluh lima persen LK terjadi 1 bulan sampai beberapa tahun setelah didiagnosis leukemia. 4,6,7,10 Tiga puluh delapan persen pasien didiagnosis pada waktu yang sama, sedangkan 7\% LK terjadi sebelum infiltrasi sel leukemia ke sumsum tulang. Keadaan ini disebut aleukemik leukemia kutis (kloroma) atau leukemia ekstramedular primer. ${ }^{1}$ Yen dkk melaporkan bahwa LK sebagai penyakit kulit yang terlokalisir mungkin menunjukkan transformasi leukemia atau mulainya leukemia akut dalam 1-20 bulan berikutnya. ${ }^{8} \mathrm{Su}$, dkk. melaporkan bahwa hal ini terjadi pada 1 dari 2 pasien dengan LMA-M4. ${ }^{10}$ Leukemia kutis juga terjadi pada $25 \%$ pasien dengan mielodisplastik sindrom yang mengalami transformasi leukemia. ${ }^{4,8,11}$

Dasar molekuler terjadinya LK masih belum diketahui, namun dilaporkan bahwa setelah pengembangan klonal sel-sel leukemia, terjadi suatu proses dari jaringan selektif yang memimpin infiltrasi sel-sel ganas ke dalam epidermis, dermis dan lemak subkutan. Studi kariotipik sel leukemia menunjukkan hubungan yang kuat antara aneuploidi kromosom 8 dan LK. Abnormalitas LK lainnya yaitu translokasi kromosom inv(3) dan t(6;9) (p23;q34). Kloroma dihubungkan dengan translokasi kromosom $\mathrm{t}(8 ; 21)$, $\mathrm{t}(9 ; 11)$ dan inv (16). ${ }^{1}$

Keterlibatan kulit pada leukemia diduga sebagai hasil suatu proliferasi lokal sel leukemia ke dalam kulit. Namun patofisiologi yang mendasari migrasi spesifik dari sel leukemia ke kulit masih belum jelas. ${ }^{1}$ Bukti penelitian melaporkan bahwa sel $\mathrm{T}$ yang berhubungan dengan antigen pada permukaan sel mieloid leukemia pada LMA-M5 dengan LK mempromosikan secara selektif proses migrasi ke kulit. ${ }^{1,6}$ Namun mekanisme yang pasti tetap sulit diuraikan, ${ }^{7}$ juga tidak jelas diketahui bagaimana infiltrasi leukemia timbul dalam kulit sebelum berada di sumsum tulang; maka ditekankan pentingnya biopsi untuk diagnosis lesi kulit yang tidak umum. ${ }^{12}$

Klasifikasi LK dapat berupa lesi spesifik dan non spesifik (leukemids). Lesi spesifik terdiri dari sel prekursor keganasan mieloid yang merupakan penyebaran dari leukemia yang agresif ke kulit. ${ }^{6}$ Gambaran lesi kulit bervariasi, umumnya tampak sebagai makula, papula dan nodul multipel, diameter $1-2,5 \mathrm{~cm}$, dengan batas tegas, teraba seperti masa yang padat kenyal, tidak gatal dan tidak nyeri (Gambar 9). 1,13,14 Kadang-kadang berbentuk plakat indurasi, ulkus, bula dan agak jarang seperti palpable purpura. Warnanya bervariasi dari merah kecoklatan, hijau sampai biru keunguan. ${ }^{1,2,8,14}$ Umumnya tidak ada riwayat peradangan, trauma, operasi maupun radiasi. Lesi tersebut dapat berkembang dengan cepat. Pada LMA-M5 lesi cenderung menjadi besar dan keunguan, ${ }^{14}$ kulit menebal terutama pada wajah. ${ }^{15}$ Beberapa peneliti melaporkan bahwa gambaran lesi kulit pada LMA-M4 berupa nodul (70\%), papula $(52 \%)$, ekimosis $(26 \%)$, plakat (22\%), purpura (17\%), makula (13\%). ${ }^{5,10,11}$ 


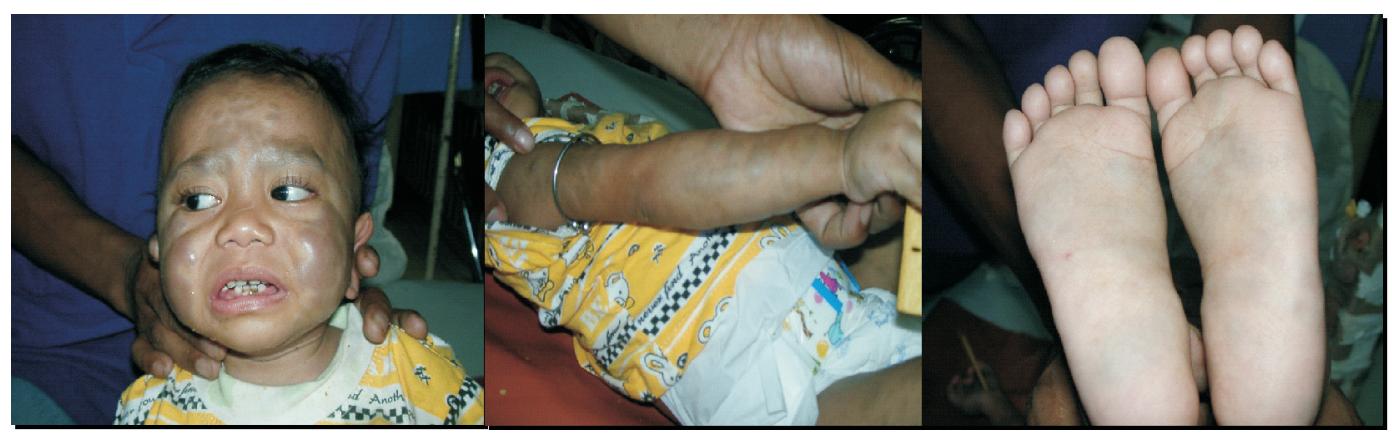

Gambar 6. Lesi kulit menebal dan menyebar sampai ke telapak kaki
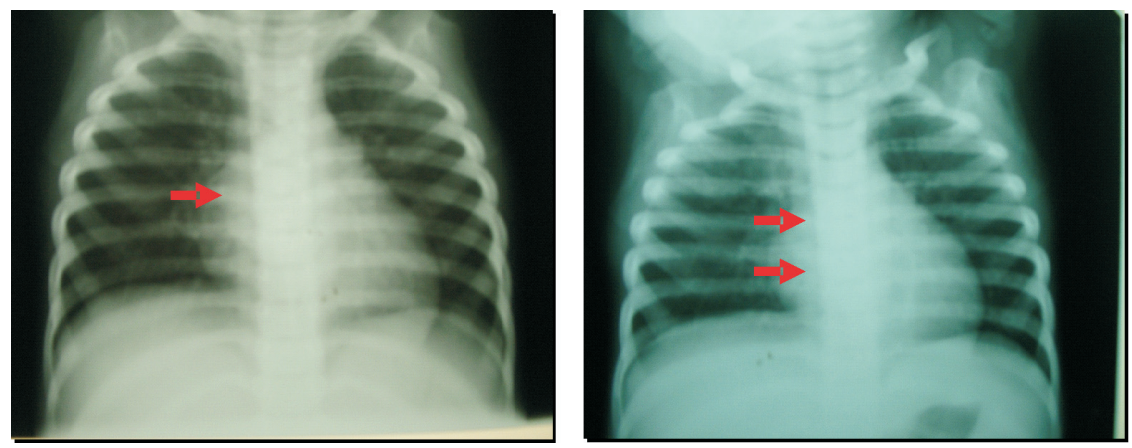

Gambar 7. Foto toraks: dijumpai peningkatan infiltrat di daerah parakardial dan perihilar
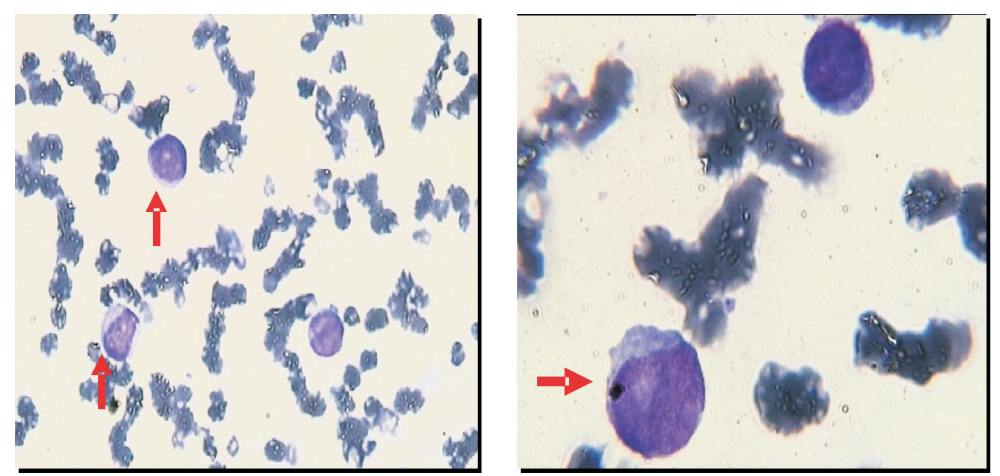

Gambar 8. Sel mieloblas pada aspirasi sumsum tulang

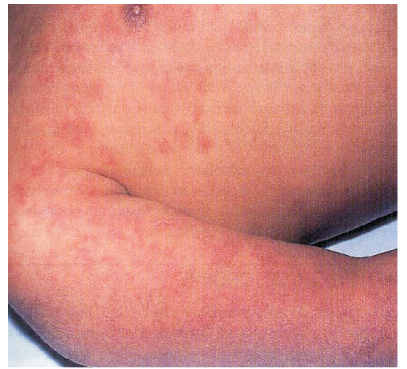

makula

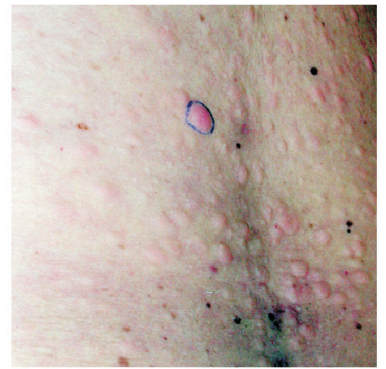

papula

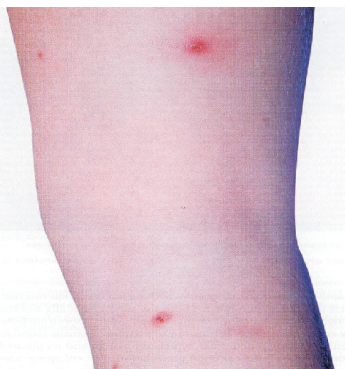

nodul

Gambar 9. Gambaran lesi kulit pada leukemia kutis 
Leukemia kutis tidak mempunyai predileksi spesifik, ${ }^{9,10}$ distribusi hampir sama pada seluruh tubuh ${ }^{5}$ dapat sebagai lesi tunggal atau menyebar pada $70 \%$ permukaan tubuh. ${ }^{8}$ Pada 50\% kasus LMA-M4 dan M5 sering terjadi hipertrofi gusi yang khas sebagai hasil dari infiltrasi leukemia (Gambar 10), ${ }^{1,11,13}$ juga timbul lesi dalam mulut yang tampak sebagai papula, nodul dan ulkus. ${ }^{10}$ Pada LMA-M4 dan M5 sering didapatkan plakat leukemik yang menyebabkan penebalan kulit kepala, alis dan pipi, sehingga tampak seperti facies leonina (Gambar 11). ${ }^{1,14}$

Gambaran lesi kulit LK lainnya dapat berupa satu nodul tumor atau multipel yang terlokalisasi sebagai infiltrasi mieloblas, tanpa adanya sel leukemia pada sumsum tulang. Hal ini dikenal sebagai sarkoma granulositik atau kloroma (Gambar 12). Tumor berwarna hijau karena pigmentasi kehijauan dengan enzim mieloperoksidase di dalam sel mieloid, ${ }^{1}$ ukuran bervariasi dengan diameter $1-3 \mathrm{~cm} .{ }^{14}$ Tumor tersebut terutama dijumpai pada anak berusia kurang dari 18 tahun, dan timbul sekitar 1 tahun sebelum didiagnosis leukemia. Selain pada kulit, tumor dapat timbul di tulang periosteum atau tulang kranial, kelenjar lakrimalis, jaringan retroorbital, kelenjar getah bening dan payudara. ${ }^{14}$

Pada leukemia kongenital, lesi nodular mempunyai tekstur kenyal dan mudah digerakkan, diameter beberapa milimeter sampai beberapa sentimeter, warna coklat kemerahan atau biru keabuan (Gambar 13). Lesi kulit ini tampak pada 50\% kasus sebagai manifestasi awal. ${ }^{14}$

Lesi kulit non spesifik juga bervariasi namun tidak ada infiltrasi leukemia ke dalam kulit. Lesi non spesifik ini terjadi pada $30-40 \%$ pasien leukemia, sering timbul sebagai purpura, petekie dan ekimosis karena trombositopenia. ${ }^{3}$ Leukemids, juga dianggap sebagai hasil dari efek toksik penyakit dasarnya, seperti papula mirip prurigo, erupsi makulopapular, lesi-lesi vesikobulosa, urtikaria, eritroderma generalisata, hiperpigmentasi eksfoliativa, eritema multiforme, sindrom Sweet dan eritema nodosum, pioderma gangrenosum, dermatitis eksfoliativa, ichthyosis, vaskulitis, eritema anulare sentrifugum, psoriasis gutata, tumor subungual, paronikia kronik.1,5,7,14

Identifikasi keterlibatan kulit pada leukemia dilakukan melalui pemeriksaan histopatologi dari biopsi kulit. Penemuan histologi pada LK bervariasi tergantung pada subtipe leukemia. Secara khas ditemukan sedikit keterlibatan epidermis, dan terdapat infiltrasi sel leukemia monomorfyang tersebar ke dalam dermis dan jaringan subkutan. Juga sering didapatkan infiltrasi di antara ikatan kolagen dan perivaskular serta periadneksal di dermis. Sel-sel mungkin juga menginfiltrasi dinding pembuluh darah, menghasilkan suatu leukemik vaskulitis. Sel-sel pada LMA adalah besar berbentuk oval, vesikular nukleus dan sitoplasma basofilik. ${ }^{1}$

Tabel 1. Rekomendasi pewarnaan imunohistokimia untuk leukemia kutis ${ }^{1}$

\begin{tabular}{|c|c|}
\hline Keturunan sel & CD Marker Antigen \\
\hline Sel T & $\begin{array}{l}\text { CD } 45 \text { (LCA) + kuat } \\
\text { CD } 45 \text { RO biasanya + kuat } \\
\text { CD } 3 \text { + tapi tersebar }\end{array}$ \\
\hline Sel B & $\begin{aligned} \text { CD 20: } & + \text { kuat tapi tersebar pada normal sel B, } \\
& + \text { lemah atau - pada sel B kecil yang abnormal, } \\
& + \text { pada abnormal sel B besar }\end{aligned}$ \\
\hline Sel granulosit & $\begin{array}{l}\text { Lysozyme + kuat pada granulosit diferensiasi baik dan buruk. } \\
\text { Chloroacetate esterase + pada granulosit dengan diferensiasi baik. } \\
\text { CD } 68 \text { biasanya negatif pada semua granulosit. }\end{array}$ \\
\hline Sel monosit & $\begin{array}{l}\text { Lysozyme + kuat pada monosit dengan diferensiasi baik dan buruk. } \\
\text { Chloroacetate esterase biasanya negatif. }\end{array}$ \\
\hline & CD 68 + pada monosit dengan diferensiasi baik. \\
\hline
\end{tabular}

\footnotetext{
Interpretasi hasil pewarnaan imunohistokimia

$0 \quad$ = reaksi negatif

$+\quad=$ reaksi + sampai $10 \%$ dari pada sel-sel neoplastik

$++\quad$ reaksi + antara $10-50 \%$ sel-sel neoplastik

$+++=$ reaksi + bila $>50 \%$ sel-sel neoplastik
} 

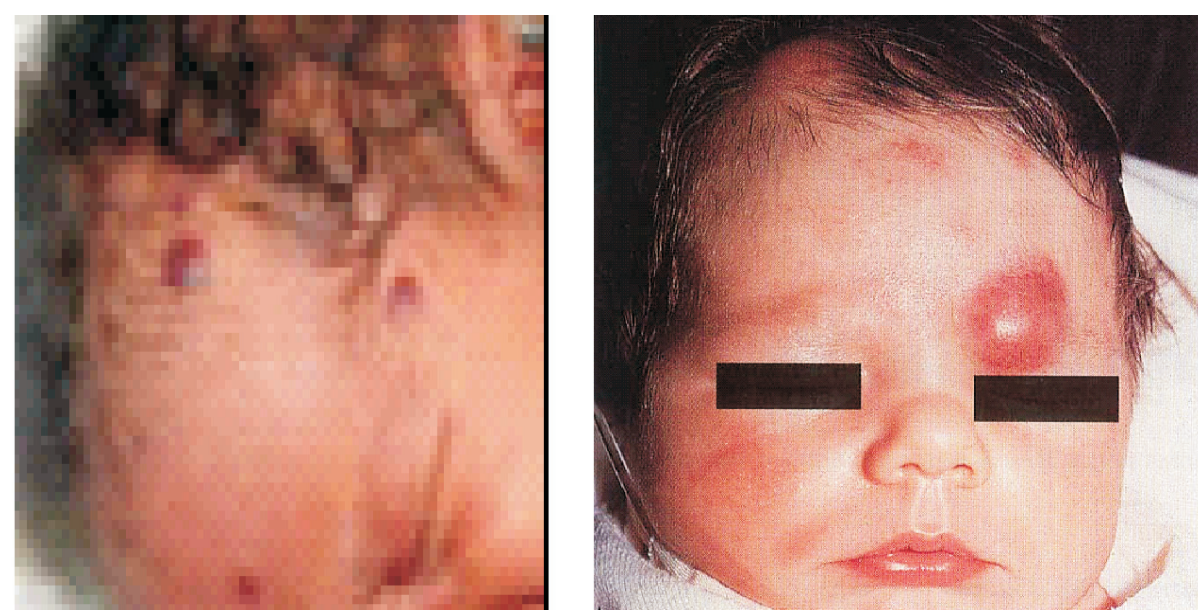

\section{Gambar 13. Blueberry muffin dan nodul besar leukemia kongenital}

Biopsi kulit dengan pewarnaan imunohistokimia merupakan kunci untuk mendiagnosis aleukemik leukemia kutis. Untuk membedakan lesi kulit yang spesifik dari non spesifik dilakukan analisis imunofenotipik lesi kulit dengan marker khusus. (Tabel 1) ${ }^{1}$

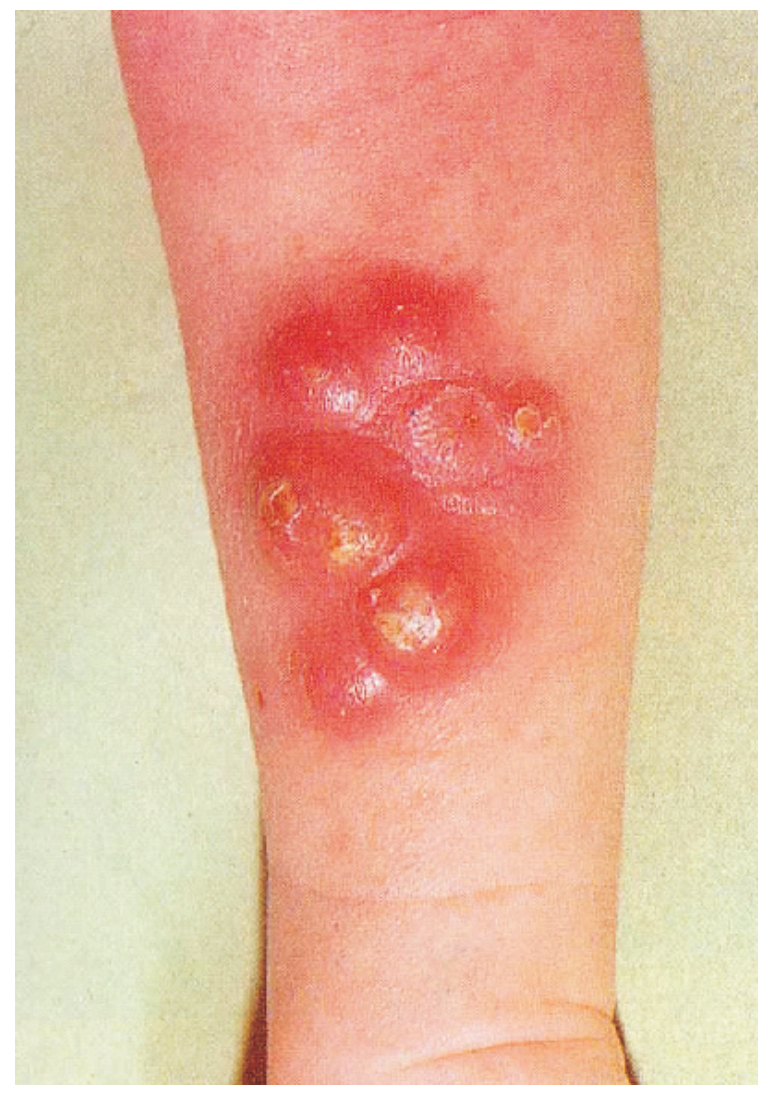

Gambar 12. Kloroma

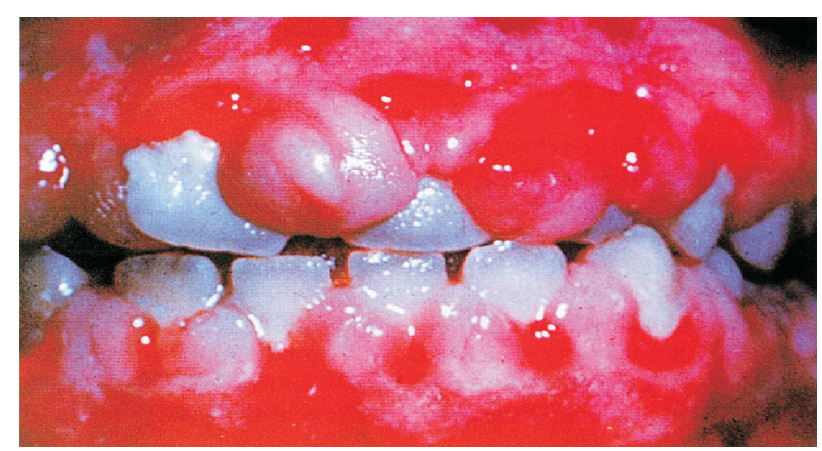

Gambar 10. Hipertrofi gusi

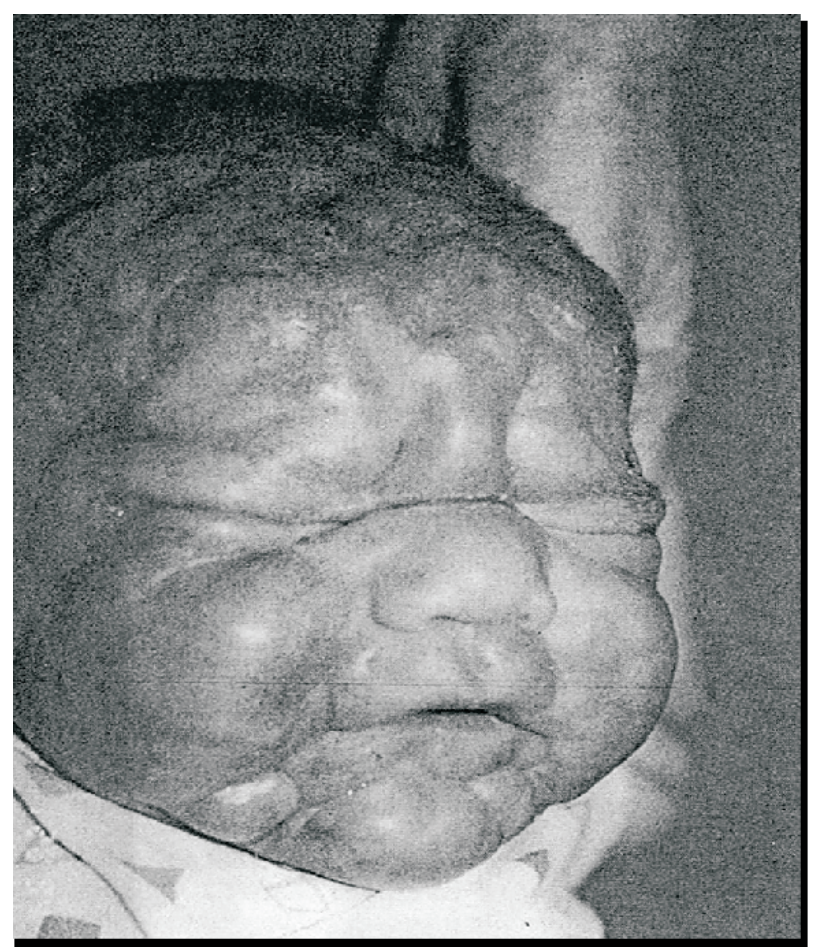

Gambar 11. Facies leonina 
Spesimen biopsi kulit untuk pemeriksaan histopatologi dan spesimen kulit yang segar untuk studi sitokimia dapat menolong dalam menentukan tipe leukemia. Pemeriksaan sitokimia dan sitomorfologi dari sumsum tulang dan apusan darah tepi juga harus dikerjakan, karena morfologi lebih jelas untuk membuat diagnosis definitif tipe leukemia. ${ }^{10,14,15}$

Kelainan kulit lain yang sering menimbulkan manifestasi seperti lesi spesifik LK adalah acute febrile neutrophilic dermatosis, drug eruptions, drug-induced ginggival hyperplasia, eritema nodosum, sindrom hipereosinofilik, limfositoma kutis, metastasis keganasan pada kulit, neutrophilic eccrine hidradenitis, pioderma gangrenosum, sarkoidosis, urtikaria vaskulitis, eksantem virus, non-hodgkin limfoma dan purpura. ${ }^{1}$

Infiltrasi sel leukemia ke kulit merupakan manifestasi lokal dari penyakit sistemik yang mendasari, maka pengobatannya adalah kemoterapi sistemik yang sesuai dengan subtipe leukemia. ${ }^{1,4}$ Pasien dengan aleukemik leukemia kutis atau sarkoma granulositik akan berkembang menjadi leukemia dan harus diobati dengan kemoterapi sejak didiagnosis. Leukemia kutis pada LMA mungkin berhasil diobati dengan kemoterapi saja, tetapi bila ada lesi kulit yang resisten atau relaps dapat diobati dengan whole body electron beam radiation diikuti dengan kemoterapi reinduksi dan konsolidasi. Namun ternyata kemoterapi sistemik yang adekuat hanya dapat menginduksi dan mempertahankan remisi sumsum tulang namun tidak dapat mengontrol LK. Sebaliknya terapi radiasi dapat mengontrol lesi-lesi kulitnya tetapi tidak dapat mencegah relaps sumsum tulangnya, karena blas dari kulit dapat menyebar kembali ke dalam sumsum tulang. Oleh sebab itu pengobatan pada LK harus termasuk pengobatan langsung pada kulit, sumsum tulang dan tempat ekstramedular lainnya. ${ }^{9}$ Keterlibatan kulit menunjukkan prognosis buruk pada leukemia. Umumnya kulit paling sering terlibat pada akhir perjalanan penyakitnya. ${ }^{2}$ Penelitian Baer, dkk. melaporkan bahwa pasien LMA dengan LK, 40\% mempunyai leukemia meningeal dan $90 \%$ mempunyai keterlibatan ekstramedular lainnya. ${ }^{9}$

Penelitian Kaddu, dkk. menyatakan bahwa dengan adanya LK pada LMA, perjalanan penyakit menjadi agresif dan kelangsungan hidup menjadi pendek yaitu antara 1-23 bulan dengan rata-rata 7,6 bulan sejak timbulnya lesi spesifik, tanpa meng- hiraukan macam pengobatan yang diberikan. ${ }^{6}$ Suatu tinjauan kepustakaan dari tahun 1965-2001 (36 tahun) melaporkan bahwa angka kelangsungan hidup rata-rata adalah $6 \%$ selama 2 tahun pada pasien LMA dengan LK dibandingkan dengan 30\% pasien LMA tanpa LK. ${ }^{1}$ Penelitian menyatakan bahwa $52 \%$ pasien tidak ada yang hidup dalam 3 bulan, $24 \%$ hidup $4-$ 9 bulan dan 24\% hidup lebih dari 10 bulan. $^{2}$

\section{Daftar Pustaka}

1. Rencic A, Ramanarayanan J. Leukemia cutis. Diperbaharui terakhir pada tanggal 29 Oktober 2003. Didapat dari URL: http://www.emedicine.com/derm/topic924. htm. Diakses pada tanggal 23 Januari 2004.

2. Shaikh BS, Frantz E, Lookingbill DP. Histologically proven leukemia cutis carries a poor prognosis in acute nonlymphocytic leukemia. Cutis 1987;39:57-60.

3. Callen JP. Vasculitis appears to be a regular feature of leukemia cutis. Didapat dari URL: http://dermatology. jwatch.org/cgi/content/full/2000/1211/6. Diakses pada tanggal 16 Januari 2004.

4. Chang H, Shih LY, Kuo TT. Primary aleukemic myeloid leukemia cutis treated successful with combination chemotherapy: report of a case and review the literature. Didapat dari URL: http://www.ncbi.nlm.nih. gov:80. Diakses pada tanggal 16 Januari 2004.

5. Burg G. Myelomonocytic leukemia. Dalam: Moschella LS, Hurley HJ, penyunting. Dermatology. Edisi ke-3. Philadelphia: WB Saunders company, 1992. h. 1841-2.

6. Kaddu S, Zenahlik P, Schmid CD, Kerl H, Cerroni L. Specific cutaneous infiltrates in patients with myelogenous leukemia: a clinicopathologic study of 26 patients with assessment of diagnostic criteria. J Am Acad Dermatol 1999;40:966-78.

7. Chao SC, Lee JYY, Tsao CJ. Leukemia cutis in acute lymphocytic leukemia masquerading as viral exanthema. The Journal of Dermatology 1999;26:216-9.

8. Yen A, Sanchez R, Oblender M, Raimer S. Leukemia cutis: Darier's sign in a neonate with acute lymphoblastic leukemia. J Am Acad Dermatol 1996;34:375-8.

9. Baer MR, BarcosM, Farrel H, Raza A, Preisler H. Acute myelogenous leukemia with leukemia cutis. Cancer 1989;63:2192-200.

10. Su WPD, Buechner SA, Li CY. Clinicopathologic correlations in leukemia cutis. J Am Acad Dermatol 1984;11:121-8. 
11. Zebisch A, Cerroni L, Beham-Schmid C, Sill H. Therapy related leukemia cutis: case study of an aggressive disorder. Didapat dari URL: http://www.ncbi.nlm.nih. gov:80. Diakses pada tanggal 16 Januari 2004.

12. Heskel NS, White CR, Fryberger S, Neerhout RC, Spraker M, Hanifin JM. Aleukemic leukemia cutis: Juvenile chronic granulocytic leukemia presenting with figurate cutaneous lesions. J Am Acad Dermatol 1983;9:423-7.

13. Chu AC. Monocytic leukemia. Dalam: Champion RH, Burton JL, Burns DA, Breathnach SM, penyunting.
Textbook of dermatology. Edisi ke-6. Oxford: Blackwell Science Ltd, 1998. h. 2334.

14. Pierini AM \& De Pierini RGD. Skin malignancies. Dalam: Harper J, Oranje A, Prose N, penyunting. Textbook of pediatric dermatology. Oxford: Blackwell Science, 2000. h. 828-30.

15. Mackie RM. Cutaneous lymphomas and lymphocytic infiltrates. Dalam: Champion RH, Burton JL, Burns DA, Breathnach SM, penyunting. Textbook of dermatology. Edisi ke-6. Oxford: Blackwell Science, 1998. h. 2397-8. 